\title{
Pekan Angan: Usaha Mengatasi Trauma Kekerasan pada Anak
}

\author{
Cyndi Sulistiawati*, Yunita Ayu Nurfadilah, Huwaida Isnaeni Harisiyah, Mutiara \\ Hanifa, Nyoman Desi Putriana, dan Puti Archianti \\ Universitas Muhammadiyah Prof. Dr. HAMKA \\ *E-mail: cyndisulistiawati@gmail.com
}

INFO ARTIKEL

\section{How to cite (APA):}

Sulistiawati, C., Nurfadilah, Y., Harisiyah, H., Hanifa, M., Putriana, N., \& Archianti, P. (2019). Pekan Angan: Usaha Mengatasi Trauma Kekerasan pada Anak. Jurnal Indonesia Mengabdi, 1(2), 34-37.

Retrieved from https://journal.stkipnurulhuda. ac.id/index.php/JIMi/article/vie w/503

\section{ISSN 2685-3035}

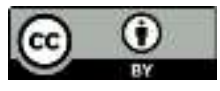

This work is licensed under a Creative Commons Attribution 4.0 International License

\section{ABSTRAK}

\begin{abstract}
Abstrak
Fenomena kekerasan pada anak saat ini marak terjadi dan belum adanya penanganan lebih lanjut untuk trauma yang dialami para korban, pada akhirnya akan mempengaruhi perilaku anak menjadi tidak percaya diri dan menjadi lebih tertutup terhadap lingkungan sekitarnya, maka kegiatan ini dilakukan untuk membantu para korban untuk mengatasi trauma tersebut agar tidak berdampak buruk pada masa depan mereka. Tim melakukan beberapa metode dimulai dari melakukan sharing untuk mencari tahu tentang seberapa jauh pengetahuan mereka tentang kekerasan dan pengalamanpengalaman kekerasan yang pernah mereka alami, lalu dilanjutkan dengan pemberian materi tentang kekerasan verbal dan nonverbal kepada anakanak, kemudian tim melakukan evaluasi untuk memastikan anak-anak memahami materi yang sudah diberikan. Hasilnya anak-anak mulai lebih memahami berbagai macam kekerasan verbal dan nonverbal. Selain itu, anak-anak yang awalnya tidak percaya diri dan tertutup menjadi lebih percaya diri di depan umum serta lebih terbuka terhadap lingkungan sekitarnya.
\end{abstract}

Kata kunci: Pekan Angan, Kekerasan, Trauma

\begin{abstract}
The phenomenon of violence against children is currently rampant and there has been no further handling of the trauma experienced by the victims, which in turn will affect the children's behavior to become unsure and become more closed to the surrounding environment, so this activity is carried out to help victims to overcome their trauma so it will not leave negative impacts on their future. The team carried out several methods starting from sharing to find out about how far their knowledge of violence and experiences of violence they had experienced, then continued with the provision of material about verbal and nonverbal violence to children, then the team conducted evaluations to ensure the children understand the material that has been given. The result is that children begin to understand further about various kinds of verbal and nonverbal violence. In addition, children who are initially unsure and closed become more confident in public and more open to their surroundings.

Keywords: Pekan Angan, Violence, Trauma
\end{abstract}

\section{PENDAHULUAN}

Kekerasan pada anak-anak sudah seringkali terjadi. Kekerasan terhadap anak yang sudah banyak terjadi tidak hanya dalam bentuk kekerasan fisik maupun seksual, tetapi juga dalam bentuk psikis, sosial, dan verbal. Istilah child abuse atau perlakuan salah terhadap anak bisa diartikan mulai dari yang bersifat fisik (physical abuse) hingga seksual (sexual abuse) dan mental psikis (mental abuse) hingga sosial (social abuse) yang bisa dikategorikan dengan kata lain adalah kekerasan struktual. (Huraerah, 2007). Bentuk-bentuk kekerasan tersebut dapat menghasilkan sebuah pengalaman 
traumatis yang membekas pada diri anak-anak. Pengalaman traumatis dapat menggoncangkan dan melemahkan pertahanan individu dalam menghadapi tantangan hidup sehari-hari. Selain itu, trauma yang didapatkan pada masa kecil akan berbekas dan berdampak dalam kehidupan anak-anak tidak hanya dalam waktu dekat, namun dapat memiliki dampak jangka panjang yang buruk pada masa dewasa anak-anak tersebut. Usia anak-anak tingkat sekolah dasar (6-12 tahun) adalah usia dimana anak mendapatkan pengalaman inti dimana pengalaman-pengalaman yang dialami anak-anak di rentang usia tersebut menjadi titik pusat perkembangan fisik, kogninisi dan psikososial anak. Maka dari itu, trauma yang didapatkan anak-anak terutama anak-anak yang masih dalam tingkat usia sekolah dasar dari perlakuan kekerasan akan mempengaruhi bagaimana cara mereka menjalankan kehidupannya di kemudian hari. Oleh karena itu, trauma yang terjadi pada anak-anak akibat dari tindak kekerasan harus segera diatasi agar tidak merusak kehidupan sang anak. Terdapat banyak cara untuk mengatasi trauma tersebut seperti: melakukan sebuah acara penyuluhan dan hiburan dengan cara yang menyenangkan seperti penyuluhan menggunakan media boneka tangan. Anak-anak terutama yang masih berada di tingkat sekolah dasar menyukai hal-hal yang lucu dan menyenangkan seperti boneka tangan yang terdiri dari berbagai macam karakter. Cara ini pernah dilakukan oleh Seto Mulyadi, seorang psikolog anak yang terkenal dimana ia menghibur anak-anak dari korban trauma operasi militer indonesia di Aceh pada tahun 2003. Dalam kegiatan pengabdian ini, kami berfokus kepada anak-anak dalam usia tingkat sekolah dasar yang memiliki trauma akibat mendapatkan perlakuan kekerasan baik secara verbal maupun nonverbal. Selain itu, fokus kegiatan pengabdian ini juga untuk memberikan pengetahuan dan pembekalan tentang kekerasan dan apa yang harus dilakukan ketika mendapatkan perlakuan tersebut pada anak-anak sekolah dasar.

SDN Kedaung Kaliangke 09 Petang memiliki 6 kelas. SD tersebut tidak memiliki guru BK khusus yang menangani permasalahan-permasalahan yang dialami siswa-siswi seperti kekerasan yang dampaknya dapat mempengaruhi proses belajar mereka. Selain itu, disekolah ini pun jarang diadakan sosialisasi atau penyuluhan tentang kekerasan yang sekarang marak terjadi dimana-mana.

Berdasarkan analisis situasi diatas maka tujuan dari kegiatan pengabdian ini adalah mengatasi trauma kekerasan yang terjadi pada siswa-siswi SDN Kedaung Kaliangke 09 Petang dengan metode PEKAN ANGAN (Pertunjukan Boneka Tangan) dimana anak-anak mendapat sarana hiburan, edukasi dan pembekalan mengenai kekerasan baik secara verbal maupun nonverbal.

\section{METODE PELAKSANAAN}

Kurangnya perhatian dari guru-guru mengenai permasalahan yang ada di kehidupan siswasiswinya seperti masalah trauma kekerasan yang mereka alami ini sangat disayangkan karena hal ini sangat mempengaruhi masa depan dan juga proses belajar siswa-siswi tersebut. Hal ini juga terjadi di SDN Kedaung Kaliangke 09 Petang. Untuk itu dalam kegiatan ini tim memberikan solusi berupa pemberian pengetahuan dan pembekalan mengenai mengatasi trauma dan tindak kekerasan dengan menggunakan metode boneka tangan yang menyenangkan dimana kegiatan ini tidak hanya mengedukasi melainkan juga menghibur siswa-siswi tersebut. Dengan dilakukannya kegiatan PEKAN ANGAN ini diharapkan dapat mengurangi trauma kekerasan yang dialami oleh siswa-siswi dan dapat menghindarkan mereka dari dampak buruk berkelanjutan yang akan mempengaruhi masa depan siswa-siswi tersebut.

Untuk mencapai target tersebut tim melakukan beberapa langkah, yaitu (1) Survey dilakukan agar kita mengatahui lokasi yang akan digunakan untuk melaksanakan program pertunjukan boneka tangan. (2) Observasi lapangan dilakukan untuk mengetahui situasi saat melakukan kegiatan pengabdian masyarakat (3) Rencana sosialisasi program pertunjukan boneka tangan kepada siswasiswi. Setelah mengikuti langkah rancangan kegiatan tersebut, pelaksanaan kegiatan dapat berlangsung dengan lancar. Peserta aktif dan antusias dalam mengikuti kegiatan pertunjukan boneka tangan, baik dalam pemberian materi maupun praktik dari materi yang diberikan. Kegiatan pelatihan ini dilaksanakan di SDN Kedaung Kaliangke 09 Petang, Jakarta Barat. Kegiatan ini dilakukan selama empat hari, yaitu tanggal 18, 26, 27, dan 29 April 2019. 


\section{HASIL DAN PEMBAHASAN}

Untuk dapat mengatasi permasalahan trauma yang terjadi pada siswa-siswi di SDN Kedaung kaliangke 09 Petang, maka tim menggunakan metode pertunjukan boneka tangan agar tercipta suasana yang seru dan menyenangkan. Dalam kegiatan ini tim menggunakan beberapa teknik yaitu pertama-tama tim melakukan sharing atau acara bertukar cerita untuk mengetahui cerita atau pengalaman mengenai trauma kekerasan verbal maupun nonverbal yang mereka alami. Lalu tim juga memberikan beberapa materi seperti bagaimana siswa-siswi harus bertindak jika mendapatkan perlakuan kekerasan, kepada siapa mereka harus melapor jika mendapatkan perlakuan tersebut dan materi budi pekerti untuk mencegah dampak buruk dari trauma kekerasan yang dapat mempengaruhi perilaku mereka. Selain itu, tim juga mengevaluasi siswa-siswi untuk memastikan apakah mereka telah memahami materi yang disampaikan dalam bentuk sebuah permainan. Dengan ketiga teknik tersebut diharapkan dapat mengatasi permasalahan yang terjadi pada mitra. Untuk mengevaluasi kegiatan ini, maka tim mewawancarai beberapa anak, guru, dan kepala sekolah guna mengetahui dampak dari kegiatan yang telah dilakukan.

Dalam usaha mengatasi kekerasan pada anak-anak, kami melakukan pertunjukan boneka tangan di SDN Kedaung Kaliangke 09 Petang sebanyak 4 kali. Pada pertemuan pertama tim melakukan acara sosialisasi dan sharing dimana siswa-siswi menceritakan pengalaman mereka ketika mendapatkan tindak kekerasan. Pertemuan kedua yaitu pemberian materi pengenalan mengenai kekerasan. Pertemuan ketiga yaitu pemberian materi mengenai pembekalan siswa-siswi untuk melindungi diri dari perlakuan kekerasan verbal maupun nonverbal. Pertemuan keempat yaitu pemberian materi tentang pihak-pihak yang dapat dihubungi ketika mendapatkan perlakuan kekerasan dan mengajarkan budi pekerti kepada siswa-siswi. Selain pemberian materi, tim juga mengadakan evaluasi dari materi yang diberikan melalui permainan yang menyenangkan. Dari permainan tersebut diketahui siswa-siswi sudah paham akan materi yang tim sampaikan dari pertemuan-pertemuan sebelumnya. Selain itu, pada pertemuan terakhir tim mengajak siswa-siswi untuk tampil memainkan boneka tangan didepan dan memperagakan materi yang sudah diberikan. Mereka terlihat lebih percaya diri saat tampil kedepan. setelah materi dan permainan tersebut siswa-siswi terlihat lebih ceria dan bersemangat.

\section{SIMPULAN}

Kesimpulan dari kegiatan kami adalah kami membuat metode pertunjukan boneka tangan sebagai sarana mengatasi trauma kekerasan pada anak-anak. Sebelum pelaksanaan kami mengadakan diskusi untuk membahas tentang konsep kegiatan yang akan kami lakukan. Lalu pada tanggal 18, 26, 27 dan 29 april 2019 kami melaksanakan kegiatan pertunjukan boneka tangan tersebut. Selama 4 pertemuan kami memberikan berbagai materi, hiburan dan permainan yang menyenangkan sehingga kegiatan tidak membosankan tetapi tetap efektif dan siswa-siswi pun turut aktif dalam kegiatan kami. Hasil dari kegiatan yang dilaksanakan tim adalah siswa-siswi menjadi paham tentang apa itu kekerasan verbal dan nonverbal. Selain itu, siswa-siswi juga menjadi lebih terbuka dan percaya diri.

\section{UCAPAN TERIMAKASIH}

Ucapan terima kasih ditujukan kepada institusi resmi atau perorangan sebagai penyandang dana, atau yang telah memberikan kontribusi lain dalam penelitian. Ucapan terima kasih dilengkapi dengan nomor surat kontrak penelitian.

\section{DAFTAR PUSTAKA}

Huraerah, Abu. (2007). Child Abuse (Kekerasan Terhadap Anak). Bandung : Nuansa

Hatta, Kusmawati. (2016). Trauma dan Pemulihannya Suatu Kajian Berdasarkan Kasus Pasca Konflik dan Tsunami. Banda Aceh : Dakwah Ar-Rainiry Press 